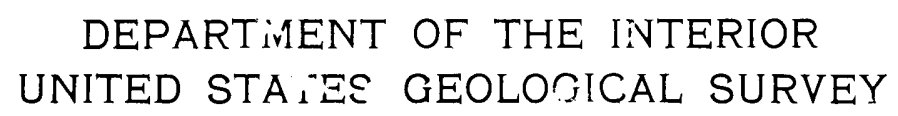

\title{
METAMORPHIC MAP OF THE APPALACHIANS By
}

Benjamin A. Morgan

\begin{abstract}
MISCELLANEOUS GEOLOGIC INVESTIGATIONS MAP I-724
\end{abstract}

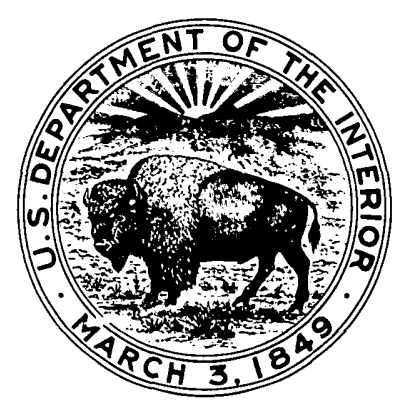

PUBLISHED BY THE U.S. GEOLOGICAL SURVEY WASHINGTON. D.C. 20242 


\title{
METAMORPHIC MAP OF THE APPALACHIANS \\ By
}

\author{
Benjamin A. Morgan
}

\section{INTRODUCTION}

This map depicts the major metamorphic belts of the Appalachian mountain system within the United States. Degree of metamorphism is expressed in terms of isograds, mineral facies, and mineral facies series.

The isograds on the accompanying map are defined by the first prograde appearance of an index mineral without regard to a specific chemical reaction and without rigor as to the chemical composition of the index mineral or chemistry of the total system. Wherever possible, isograds are shown in rocks of approximately similar total composition. A more rigorous definition and use of an isograd was not practicable, owing to the necessity of compiling information from a wide variety of reports and broad extrapolation in many areas. The isograds used for rocks of pelitic composition are biotite, garnet, andalusite, kyanite, sillimanite, and sillimaniteorthoclase. The complete set of isograds is used only in New England and New York; insufficient information for the occurrence of biotite and kyanite prevented depiction of these isograds throughout the southeastern Appalachians.

Mineral facies and mineral facies series, as used here, are defined on the basis of the isograd data and are at some variance with definitions proposed by several writers (Fyfe and Turner, 1966; Winkler, 1967). The facies of metamorphism are mineral facies based on key minerals from pelitic rocks rather than ensembles of mineral assemblages from specific localities (Thompson, 1957). The granulite facies is defined by the assemblage quartz-sillimanite-orthoclase in rocks of pelitic composition. The epidote-amphibolite and almandine amphibolite facies have been combined as the amphibolite facies and are delimited by the garnet and sillimanite-orthoclase isograds. The greenschist facies includes all masses of rock of pelitic composition that do not contain garnet.

The lower limit of greenschist metamorphism and the boundary between metamorphism and diagenesis are nut defined. This poses no problems in map compilation along the entire eastern and southern margins of the Appalachians where the greenschist and amphibolite facies rocks are unconformably overlain by unmetamorphosed rocks of the Atlantic and Gulf Coastal Plain. In areas where a continuous gradation between greenschist and unmetamorphosed rocks exists, a subgreenschist or transitional facies of metamorphism has been recognized. The two principal areas designated as subgreenschist facies are northern Maine and Cambrian-Ordovician units within the Great Valley and the eastern part of the Ridge and Valley provinces in the central and southern Appalachians. The subgreenschist facies in northern Maine is the area designated as a subchlorite zone by Hussey and others (1967). Coombs, Horodyski, and Naylor (1970) have reported the occurrence of a prehnite-pumpellyite facies within a part of this area. Formations within the Great Valley and the Valley and Ridge provinces may or may not be regarded as metamorphosed (see for example Ray and Gault, 1961; Maxwell, 1962; Drake, 1969) depending on the definitions used. Although A. A. Drake, Jr. (oral commun., 1970) has evidence that much of the Martinsburg Formation in the Great Valley province of eastern Pennsylvania is metamorphosed to the greenschist facies, the western boundary of the subgreenschist facies is arbitrarily taken as the western contact of the Martinsburg Formation within eastern Pennsylvania and the western boundary of Cambrian-Ordovician rocks east of the Pulaski fault in Virginia and Tennessee and southeast of the Rome fault in Georgia. The occurrence of pumpellyite at Bunker Hills, Pa. (Zen, 1971), and prehnite in the greenstones of the Catoctin Formation near Luray, Va. (W. G. Melson, oral commun., 1969), indicates a possibility of a widespread prehnitepumpellyite metamorphic facies within these rocks heretofore undetected because of the limited number of investigations and the limited occurrence of rocks of the prerequisite chemical composition.

Laumontite-quartz-albite assemblages have been described in arkoses in the Connecticut Triassic basin (Heald, 1956). These rocks may be in a zeolite facies, but this metamorphism is clearly post-Paleozoic and not related to other metamorphic episodes shown on the map. The laumontite-quartz-albite assemblages are not transitional into areas of prehnite-pumpellyite or greenschist metamorphic facies. These rocks are indicated on the map by the letter $\mathrm{z}$.

Two facies series have been recognized in the Appalachians: a low pressure/temperature (P/T) 
facies series in the northern part of New England and an intermediate $\mathrm{P} / \mathrm{T}$ facies series in the remainder of the Appalachians. These facies series are defined by the polymorphic transitions of andalusite to sillimanite and kyanite to sillimanite, respectively. There are no occurrences of glaucophane, metamorphic aragonite, jadeite, or lawsonite in the eastern. United States to define a high $\mathrm{P} / \mathrm{T}$ facies series.

\section{PRECAMBRIAN METAMORPHIC BELTS}

The areas shown in shades of brown represent the oldest rocks known in the Appalachians. The Adirondack massif was metamorphosed during the Precambrian but not by subsequent Paleozoic metamorphic events. The Adirondack massif, flanked by unmetamorphosed Paleozoic rocks, is a part of the Precambrian basement of Grenville age that may underlie the unmetamorphosed fold belt along the west flank of the Appalachian mountain system. In the area of the Adirondack massif, this basement has not been extensively modified by Paleozoic metamorphism except for cataclastic shearing and local retrogression along the eastern and southeastern margins. The greater part of the Adirondacks is considered to be in the granulite facies (Buddington, 1963; Waard, 1965) defined by an orthopyroxeneclinopyroxene-hornblende isograd (h) in rocks of basaltic composition and the widespread occurrence of the assemblage quartz-sillimanite-orthoclase in rocks of appropriate composition. In the northwestern Adirondacks, the regional metamorphism is in the amphibolite facies; sillimanite is abundant, cordierite is present, kyanite is absent. The progressive metamorphism from amphibolite to granulite facies described by Engel and Engel $(1958,1960)$ is probably typical of a low $\mathrm{P} / \mathrm{T}$ facies series.

The darker brown areas represent the Precambrian infrastructure within the Appalachian system. These areas are polymetamorphic and have been metamorphosed 1.1 to 0.8 b.y. B. P. and again during the Paleozoic approximately 0.50 to 0.23 b.y. B. P. These rocks are unconformably overlain by sedimentary and volcanic rocks which have a metamorphic history restricted to the Paleozoic. The distribution of older, polymetamorphic Precambrian rocks in New England and in the central Appalachians is moderately well known. One problematic area is southeastern Massachusetts where $\mathrm{Rb}-\mathrm{Sr}$ whole rock ages on granites are near a 540 m.x. isochron (Fairbairn and others, 1965). Although these rocks are shown on the map as Paleozoic granites, further work in this area may conclusively determine a Precambrian age. The distribution of Precambrian rocks in the region south of the Potomac may more accurately reflect the extent of geologic mapping and radiometric age determinations rather than the true distribution of older Precambrian rocks. Recent mapping by Espenshade and Rankin (1970) revealed a large area of Precambrian rocks within the Inner Piedmont of
North Carolina and Virginia which had not been previously described.

Although the degree of Precambrian metamorphism is variable within the polymetamorphic belt, the greenschist facies is absent throughout. Relict orthopyroxene and sillimanite in quartzo-feldspathic rocks are present in a wide area from the Hudson highlands of New York southward to about the North Carolina-Virginia boundary. Retrograde rocks similar to charnockites have been described in the core of the Blue Ridge anticlinorium (Bloomer and Werner, 1955). Relict orthopyroxene (dotted overprint) survives only in the western part of the older Precambrian belt where the Paleozoic metamorphic overprint is in the lower greenschist facies (an important exception being the Wilmington complex described by Ward, 1959). Consequently it is difficult to depict the earlier distribution of the granulite facies of metamorphism. The prevalence of a granulite mineral facies and the general radiometric age bracket for these rocks suggest that they are broadly correlative with rocks of the New Jersey highlands and the Adirondacks in New York.

\section{PALEOZOIC METAMORPHIC BELTS}

In New England and in the southeastern Appalachians, three major longitudinal axes of higher grade metamorphism (amphibolite and granulite mineral facies) of Paleozoic age are separated by areas of lower grade metamorphism (greenschist facies and garnet zone of amphibolite facies). In New England, these three belts include an outer or northwestern belt extending from the Manhattan prong northward through the core of the Green Mountain anticlinorium, a central belt comprising central Connecticut and Massachusetts, New Hampshire, and western Maine, and finally a southeastern belt, including Rhode Island, eastern Massachusetts, and the southern tip of Maine. Analogous belts in the southeastern Appalachians are a western belt in the Blue Ridge anticlinorium of North Carolina and Georgia, a central belt or Inner Piedmont extending from Alabama northeast through central Virginia to southeastern Pennsylvania, and a poorly exposed southeastern belt extending from Macon, Ga., through Columbia, S. C., to eastern North Carolina and east-central Virginia.

The persistence of metamorphic axes along linear belts within the Appalachians over great distances poses important problems in interpretation. Are the patterns principally related to thermal distributions during the Paleozoic Era or are they a result of structural deformation after regional metamorphism over the entire area? If the linear belts were of thermal rather than of mechanical origin in terms of their present outcrop pattern, were the belts formed simultaneously or as a result of successive thermal migrations in time? At present there seems to be no clear answer to these questions. In New England, 
the: limeaur beltt: off greemschnisitt allomgr the: eastt boirdler off the Greem Moumtaiin amticliimorium is imbinmatelly rellatted tor thrusitimgs.. Thompsom amdl otthers: (19.68)) huave dlemoms;tratted thatt: isogradls have: beem over-

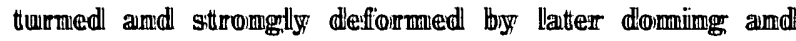
empilacememt: off mappes derived firom a previousily meatted easiterily" source.- Om the: outher hamd, Cllark amd Kullp ((1968)) im a stumdly' off the isotopice agge ouf mettamorphisim im westerm Commecticurt; amd soultheassterm New York foumd three periodss off mettamo:rpithisim wwithim the outter or morthwesterm bellt of the New Eingolamd Appallachiams; wiitth agres; off 48:0-46:0), 360), and 255 m.y. These age groups tramsilate successiivelly' from morthurest, to somtheasit. A metalmourphice evemtt writth am agge: off 2T(0)-230). m-y/. has beem associatted im Newr Fingllamd with the southeasiterm

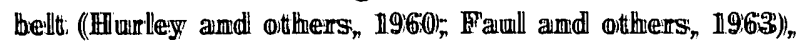
whereasi am agge: off 400)-350) m.y. seemsi welll esitalbilisithed fior the: mettamiorphinic evemt: in the cemurall bellt: ([F'aull and outhers, 19.69;; Zaurtmam and oithers, 19.65)).

Im the: southeasiterm Alppallachniams, rellatiomsthipsi are broadlly amallogrous:. The westerm metamornthic bellt; im the Bture: Riidge amtiellimoniumm iss separratted firom the: cemtrall mettamionphice bellt, off the Immer Piedimomitt bouth byy a lower gradle kypamitte-sitaumollitte zome: and by a proffoumdl sitructurall disilocattiom (tthe Breward zome)).

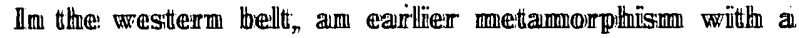

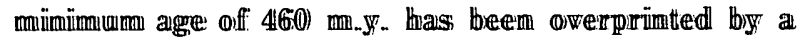
metamorphinic: exemt im the gemerall ramge: off 3801-360) mu.y7. ([Lomgr and outhers, 195991)). Throughoult: the southeassterm Alppallacthians; hisistograms off alll dattes firom alll arreas pointt: to a piromoumeed maximum for a 360)-m.y. evemt (HIadlleys, 19644). Hlowever, the easterm metamiorpthice beilt; att Ralleigh, $\mathbf{N} . \mathbb{C}_{-,}$, amd

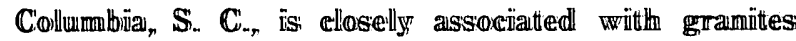
dlatted att 260)-230) amdl 230) m-y/n, respectivelly (Lomg. aund outhers; 1959); K ullp amd Eickellmamm, 1961).

The majior metamorplmic partterms im the southeasterm Appiallachiaums are remaurkable im thatt the isograids do mott form comentric patterms albount each outher but cllase or themsellves (for examplle, the sillimamite isograd im the Immer Piedmomt belt and the garmet isograd in the James River symelimoriom im westcenitrall Vurginia). Such a patterm is more suggestive of latter broad-scalle arching of the metamorphic terrane which grossily distorted the sthapes of the isograds so that they resemble patterms of plumging anticlines and symelimes.

In 1961, Miyashiro proposed the term metamorphic facies series to describe sets of mineral facies characteristic of a unique geothermal gradient operative during the metamorphism of a given terrane. He also documented evidence that on the Pacific margins, metamorphic belts of nearly synchronous age are present in pairs so that the outer or seaward beit was metamorphosed by a high $\mathrm{P} / \mathrm{T}$ geothermal gradient, whereas the inner or landward belt was metamorphosed by a low $\mathrm{P} / \mathrm{T}$ geothermal gradient. Zwart (1967) has characterized the metamorphic belts of Europe in terms of facies series; allthough clearly defined facies series are presemt im Europe, the presence of paired bellts was mot: demomsitrated. The greater part: off the Appallachiams withim the Umited Stattes hass the classicall barroriam type of prograde metamorphism (where: mimerall zomes are chlorite, biotite, garmet; sttaurullite, kyamite; amd sillimanite) designated ass am imtermediatte temperature, intermediate pressure facies series- However, im cemtrall New Eimgland, the tramsittiom of kyamite to sillimamite is replaced by the tramsittiom off amdallusite to sillimamite indicating a ehamge to a highther geothermall gradient. A heavy dasthedl lime marks the common boundary between the: tho facies serries (Thompsom and Norton, 1968). The change from am imtermediate $P / T$ to a low $P / T$ facies series is moteworthy im that the change is transverse to structurall and metamorpthic trends rather tham paralliell as im the paired metamorphic belts of the Paciffic rim deseribed by Miyashiro.

The gramulite metamorphic facies, defined by the bireakdowm of muscovite + quartz to orthoclase + sillinmamitte is widelly developed in New England (Ëwams amd Güdotti, 1966; Lumdgren, 1966) but is. albsemt in the southeasterm Appallachians. Cordierite, condierite-amthophyllite, amd andalusite-bearing assembilagess are widlely developed in New England. Soutth off the Potomac, however, cordierite almost vamishes, although severall localities are known (Sallottii and Fouts, 1967). Andalusite is very rare im greemschist rocks of Georgia and Alabama. These dlata seem to imdieatte that higher temperatures and lower pressures prevailled im metamorphism in New Eimglland than in the southeast.

A hight geothermal gradient in New England quallitatively is suggested by the absolute spacing of gairmett and sillimanite isograds. In New England the garmet amd sillimanite isograds are often separated by omly a few milles, whereas in most of the southeast, the separation is on the order of tens of miles. Although structural complications undoubtedly play a role in the distribution of the isograds and on their juxtaposition, sueh a general characteristic over hundreds of milles of metamorphic terrane is more likely related to a geothermal gradient higher in New England than in the southeast.

Calc-alkalic plutonic rocks are shown in pink. No distinction is made with regard to the age of these rocks; all are believed to be of Paleozoic age. Correlation of areas of intense plutonic activity and of sillimanite produced by regional metamorphism is not good when considering the entire Paleozoic Era. Post-Ordovician granites of New England transect isograds bounding the northern and northeastern limits of the "sillimanite plateau." In the southeastern Appalachians, the large plutonic belt near Charlotte, N. C., is east of the sillimanite zone in the Inner Piedmont. Sillimanite occurrences in eastern North Carolina and in Maryland are more closely related to later doming than to plutonic activity. 
However, a much better correlation between plutonic activity and metamorphism is observed for a few specific areas. As pointed out by Thompson and Norton (1968) the New Hampshire Plutonic Series defined by Billings $(1937,1956)$ crops out within areas of higher metamorphic grade. In northern Vermont the sillimanite isograd is deflected around small plutonic bodies in a pattern more characteristic of contact rather than regional metamorphism. In North Carolina the Raleigh area is underlain by a large batholithic complex which is also enclosed by kyanite and garnet isograds (Parker, 1968).

Ultramafic bodies are not shown. Outcrops of these rocks have been compiled by Larrabee (1966). It is interesting to note that the great majority of ultramafic bodies are associated with the westernmost metamorphic culmination both in New England and in the southeastern Appalachians in or near a terrane underlain by a Precambrian continental crust.

\section{REFERENCES CITED}

Billings, M. P., 1937, Regional metamorphism of the Littleton-Moosilauke area, New Hampshire: Geol. Soc. America, v. 48, no. 4, p. 463-566.

1956, The geology of New Hampshire; Part II, Bedrock geology: Concord, N.H., State Plan. Devel. Comm., 203 p.

Bloomer, R. O., and Werner, H. J., 1955, Geology of the Blue Ridge region in central Virginia: Geol. Soc. America Bull., v. 66, no. 5, p. 579-606.

Buddington, A. F., 1963, Isograds and the role of $\mathrm{H}_{2} \mathrm{O}$ in metamorphic facies of orthogneisses of the northwest Adirondack area, New York: Geol. Soc. America Bull., v. 74, no. 9, p. 1155-1181.

Clark, G. S., and Kulp, J. L., 1968, Isotopic age study of metamorphism and intrusion in western Connecticut and southeastern New York: Am. Jour. Sci., v. 266 , no. 10 , p. 865-894.

Coombs, D. S., Horodyski, R. J., and Naylor, R. A., 1970, Occurrence of prehnite-pumpellyite facies metamorphism in northern Maine: Am. Jour. Sci., v. 268, no. 2, p. 142-156.

Drake, A. A., Jr., 1969, Precambrian and lower Paleozoic geology of the Delaware Valley, New Jersey-Pennsylvania, in Subitzky, Seymour, ed., Geology of selected areas in New Jersey and eastern Pennsylvania and guidebook of excursions: New Brunswick, N. J., Rutgers Univ. Press, p. 51-131.

Engel, A. E. J., and Engel, C. G., 1958, Progressive metamorphism and granitization of the major paragneiss, northwest Adirondack Mountains, New York; Part I, Total rock: Geol. Soc. America Bull., v. 69 , no. 11 , p. $1369-1414$.

1960, Progressive metamorphism and granitization of the major paragneiss, northwest Adirondack Mountains, New York; Part II, Mineralogy: Geol. Soc. America Bull., v. 71, no. 1, p. 1-57.

Espenshade, G. H., and Rankin, D. W., 1970, Probable
Precambrian crystalline rocks in the Sauratown Mountains anticlinorium, a major structural feature in the Piedmont of North Carolina [abs.]: Geol. Soc. America, Abstracts with Programs, v. 2, no. 3, p. 207.

Evans, B. W., and Guidotti, C. V., 1966, The sillimanitepotash feldspar isograd in western Maine, U.S.A.: Contr. Mineralogy and Petrology, v. 12, no. 1, p. 25-62.

Fairbairn, H. W., Moorbath, S., Ramo, A., Pinson, H. W., and Hurley, P. M., 1965, Rb-Sr whole rock isotopic analyses and the Cambrian-Precambrian problem in southeastern Massachusetts [abs.]: Am. Geophys. Union Trans., v. 46, no. 1, p. 173.

Faul, Henry, Stern, T. W., Thomas, H. H., and Elmore, P. L. D., 1963, Ages of intrusion and metamorphism in the northern Appalachians: Am. Jour. Sci., v. 261, no. 1, p. 1-19.

Fyfe, W. S., and Turner, F. J., 1966, Reappraisal of the concept of metamorphic facies: Contr. Mineralogy and Petrology, v. 12 , no. 4 , p. 354-364.

Hadley, J. B., 1964, Correlation of isotopic ages, crustal heating and sedimentation in the Appalachian region, in Tectonics of the southern Appalachians: Virginia Polytech. Inst., Dept. Geol. Sci. Mem. 1, p. 33-44.

Heald, M. T., 1956, Cementation of Triassic arkoses in Connecticut and Massachusetts: Geol. Soc. America Bull., v. 67, no. 9, p. 1133-1154.

Hurley, P. M., Fairbairn, H. W., Pinson, W. H., and Faure, G., 1960, K-Ar and Rb-Sr minimum ages for the Pennsylvanian section in Narragansett Basin: Geochim. et Cosmochim. Acta, v. 18, nos. 3-4, p. 247-248.

Hussey, A. M., Chapman, C. A., Doyle, R. G., Osberg, P. H., Pavlides, Louis, and Warner, Jeffrey, comps., 1967, Preliminary geologic map of Maine: Augusta, Me., Maine Geol. Survey, scale $1: 500,000$.

Kulp, J. L., and Eckelmann, F. D., 1961, Potassiumargon isotopic ages on micas from the southern Appalachians, in Geochronology of rock systems: New York Acad. Sci. Annals, v. 91, art. 2, p. 408419.

Larrabee, D. M., 1966, Map showing distribution of ultramafic and intrusive rocks from northern New Jersey to eastern Alabama: U.S. Geol. Survey Misc. Geol. Inv. Map I-476, scale 1:500,000.

Long, L. E., Kulp, J. L., and Eckelmann, F. D., 1969, Chronology of major metamorphic events in the southeastern United States: Am. Jour. Sci., v. 257, no. 8 , p. 585-603.

Lundgren, L. W., 1966, Muscovite reactions and partial melting in southeastern Connecticut: Jour. Petrology, v. 7, no. 3, p. 421-453.

Maxwell, J. C., 1962, Origin of slaty and fracture cleavage in the Delaware Water Gap area, New Jersey and Pennsylvania, in Petrologic studies-A volume in honor of A. F. Buddington: New York, 
Geol. Soc. A merica, p. 281-311.

Miyashiro, Akiho, 1961, Evolution of metamorphic belts: Jour. Petrology, v. 2, no. 3, p. 277-311.

Parker, J. M., 1968, Structure of easternmost North Carolina Piedmont: Southeastern Geology, v. 9, no. 3, p. 117-132.

Ray, Satyabrata, and Gault, H. R., 1961, Mineralogy of Jacksonburg (Middle Ordovician) formation in eastern Pennsylvania and western New Jersey: Am. Assoc. Petroleum Geologists Bull., v. 45, no. 1, p. 39-50.

Salotti, C. A., and Fouts, J. A., 1967, An occurrence of cordierite-garnet gneiss in Georgia: Am. Mineralogist, v. 52 , nos. 7-8, p. 1240-1243.

Thompson, J. B., Jr., 1957, The graphical analysis of mineral assemblages in pelitic schists: Am. Mineralogist, v. 42 , nos. $11-12$, p. $842-858$.

Thompson, J. B., Jr., and Norton, S. A., 1968, Paleozoic regional metamorphism in New England and adjacent areas, in Zen, E-an, and others, eds., Studies of Appalachian geology-northern and maritime: New York, Interscience Publishers, p. 319-327.

Thompson, J. B., Jr., Robinson, Peter, Clifford, T. N., and Trask, N. J., 1968, Nappes and gneiss domes in west-central New England, in Zen, E-an and others, eds., Studies of Appalachian geology-northern and maritime: New York, Interscience Publishers, p. 203-218.

Waard, D. de, 1965, The occurrence of garnet in the granulite-facies terrane of the Adirondack highlands: Jour. Petrology, v. 6, no. 1, p. 165-191.

Ward, R. F., 1959, Petrology and metamorphism of the Wilmington complex, Delaware, Pennsylvania, and Maryland: Geol. Soc. America Bull., v. 70, no. 11, p. $1425-1458$.

Winkler, H. G. F., 1967, Petrogenesis of metamorphic rocks: 2d ed. rev., New York, Springer-Verlag, $237 \mathrm{p}$.

Zartman, Robert, Snyder, George, Stern, T. W., Marvin, R. F., and Bucknam, R. C., 1965, Implications of new radiometric ages in eastern Connecticut and Massachusetts: U.S. Geol. Survey Prof. Paper 525-D, p. D1-D10.

Zen, E-an, 1971, Pumpellyite-bearing metamorphic rocks from the west side of the northern Appalachian region [abs.]: Geol. Soc. America, Abstracts with Programs, v. 3 , no. 1, p. 64-65.

Zwart, H. J., 1967, The duality of orogenic belts: Geol. en Minjbouw, v. 46, no. 8, p. 283-309.

\section{PRINCIPAL SOURCES OF INFORMATION USED IN COMPILATION}

The principal sources for data used in the compilation are listed by area below. The compilations by Goldsmith (1964) and Thompson and Norton (1968) of Paleozoic metamorphism in New England have been an invaluable aid, and the author wishes to make a special acknowledgment of these papers. Several compilations and excellent summary papers are available for New England and New York. However, in the southeastern Appalachians, few such papers have been written, and the reference list is correspondingly longer for such areas.

\section{GENERAL}

Reed, J. C., Jr., 1970, Tectonic map of the central and southern Appalachians: in Fisher, G. W., and others, eds., Studies of Appalachian geologycentral and southern: New York, Interscience Publishers.

U.S. Geological Survey and American Association of Petroleum Geologists, 1961, Tectonic map of the United States, exclusive of Alaska and Hawaii: Washington, D.C., U.S. Geol. Survey, 2 sheets, scale $1: 2,500,000$.

White, W. S., 1968, Generalized geologic map of the northern Appalachian region, in Zen, E-an, and others, eds., Studies of Appalachian geologynorthern and maritime: New York, Interscience Publishers.

\section{NEW ENGLAND}

Billings, M. P., 1956, The geology of New Hampshire; Part II, Bedrock geology: Concord, N.H., State Plan. Devel. Comm., 203 p.

Coombs, D. S., Horodyski, R. J., and Naylor, R. S., 1969, Occurrence of prehnite-pumpellyite facies metamorphism in northern Maine: Am. Jour. Sci., v. 268, no. 2, p. 142-156.

Doll, C. G., Cady, W. M., Thompson, J. B., Jr., and Billings, M. P., comps. and eds., 1961, Centennial geologic map of Vermont: Montpelier, Vt., Vermont Geol. Survey, scale 1:250,000.

Goldsmith, Richard, 1964, Geologic map of New England-metamorphic zones: U.S. Geol. Survey open-file map, scale 1:1,000,000.

Heald, M. T., 1956, Cementation of Triassic arkoses in Connecticut and Massachusetts: Geol. Soc. America Bull., v. 67, no. 9, p. 1133-1154.

Hussey, A. M., Chapman, C. A., Doyle, R. G., Osberg, P. H., Pavlides, Louis, and Warner, Jeffrey, comps., 1967, Preliminary geologic map of Maine: Augusta, Me., Maine Geol. Survey, scale $1: 500,000$.

Thompson, J. B., and Norton, S. A., 1968, Paleozoic regional metamorphism in New England and adjacent areas, in Zen, E-an, and others, eds., Studies of Appalachian geology-northern and maritime: New York, Interscience Publishers, $p$. 319-327.

\section{NEW YORK}

Barth, T. F. W., 1936, Structural and petrologic studies in Dutchess County, New York; Part II, Petrology and metamorphism of the Paleozoic rocks: Geol. Soc. America Bull., v. 47 , no. 6 , p. $775-850$.

Buddington, A. F., 1963, Isograds and the role of 
$\mathrm{H}_{2} \mathrm{O}$ in metamorphic facies of orthogneisses of the northwest Adirondack area: Geol. Soc. America Bull., v. 74, no. 9, p. 1155-1182.

Buddington, A. F., and Leonard, B. R., 1962, Regional geology of the St. Lawrence County magnetite district, northwest Adirondacks, New York: U.S. Geol. Survey Prof. Paper 376, 145 p.

Engel, A. E. J., and Engel, C. G., 1958, Progressive metamorphism and granitization of the major paragneiss, northwest Adirondack Mountains, New York; Part I, Total rock: Geol. Soc. America Bull., v. 69, no. 11, p. 1369-1414.

1960, Progressive metamorphism and granitization of the major paragneiss, northwest Adirondack Mountains, New York; Part II, Mineralogy: Geol. Soc. America Bull., v. 71, no. 1, p. 1-57.

New York State Museum and Science Service, Geological Survey, 1962, Geologic map of New York, 1961: New York State Mus. and Sci. Service, Geol. Survey Map and Chart Ser., no. 5, 5 map sheets; text: The geology of New York State, by J. G. Broughton, D. W. Fisher; Y. W. Isachsen, and L. V. Rickard, $42 \mathrm{p}$.

Waard, D. de, 1965, The occurrence of garnet in the granulite-facies terrane of the Adirondack highlands: Jour. Petrology, v. 6, no. 1, p. 165-191.

\section{NEW JERSEY-PENNSYLVANIA}

Agron, S. L., 1950, Structure and petrology of the Peach Bottom slate, Pennsylvania and Maryland, and its environment: Geol. Soc. America Bull., v. 61 , no. 11;p. 1265-1306.

Bayley, W. S., 1941, Pre-Cambrian geology and mineral resources of the Delaware Water Gap and Easton quadrangles, New Jersey-Pennsylvania: U.S. Geol. Survey Bull. 920, 98 p.

Cloos, Ernst, and Hietanen, A. M., 1941, Geology of the "Martic overthrust" and the Glenarm Series in Pennsylvania and Maryland: Geol. Soc. America Spec. Paper 35, $207 \mathrm{p}$.

Hague, J. M., Baum, J. L., Herrmann, L. A., and Pickering, R. J., 1956, Geology and structure of the Franklin-Sterling area, New Jersey: Geol. Soc. America Bull., v. 67, no. 4, p. 435-473.

Hotz, P. E., 1952, Magnetite deposits of the Sterling Lake, New York-Ringwood, New Jersey, area: U.S. Geol. Survey Bull. 982-F, p. 153-244.

McKinstry, H. E., 1949, Mineral isograds in southeastern Pennsylvania: Am. Mineralogist, v. 34, nos. 11-12, p. 874-892.

1961, Structure of the Glenarm Series in Chester County, Pennsylvania: Geol. Soc. America Bull., v. 72, no. 4, p. 557-577.

Sims, P. K., 1953, Geology of the Dover magnetite district, Morris County, New Jersey: U.S. Geol. Survey Bull. 982-G, p. 245-305.

1958, Geology and magnetite deposits of Dover district, Morris County, New Jersey: U.S.
Geol: Survey Prof. Paper 287, 162 p.

Stose, A. J.; and Stose, G. W., 1944, Geology. of the Hanover-York district: U.S. Geol. Survey. Prof. Paper 204, 84 p.

Weiss, Judith, 1949, Wissahickon Schist at Philadelphia: Geol. Soc. America Bull., v: 60, no. 10, p. 16891726.

Wherry, E. T., 1918, Pre-Cambrian sedimentary rocks in the highlands of eastern Pennsylvania: Geol. Soc. America Bull., v. 29, p. 375-392.

\section{MARYLAND-DELAWARE}

Broedel, C. H., 1937, The structure of the gneiss domes near Baltimore Maryland: Maryland Geol. Survey [Rept.], v. 13, p. 149-187.

Cleaves, E. T., Edwards, Jonathan, and Glaser, J. D., comps. and eds., 1968, Geologic map of Maryland: Baltimore, Md., Maryland Geol. Survey, scale $1: 250,000$.

Cloos, Ernst, and Hietanen, Anna, 1941, Geology of the "Martic overthrust" and the Glenarm Series in Pennsylvania and Maryland: Geol. Soc. America Spec. Paper 35, $207 \mathrm{p}$.

Cloos, Ernst, Hopson, C. A., and Fisher, G. W., 1964, The geology of Howard and Montgomery Counties: Baltimore, $\mathrm{Md}$., Maryland Geol. Survey, $373 \mathrm{p}$.

Cohen, C. J., 1937, Structure of the metamorphosed gabbro complex at Baltimore, Maryland: Maryland Geol. Survey [Rept.], v. 13, p. 215-236.

Fisher, G. W., 1963, The petrology and structure of the crystalline rocks along the Potomac River, near Washington, D.C.: Baltimore, Md., Johns Hopkins Univ., Ph.D. dissertation.

Herz, Norman, 1951, Petrology of the Baltimore Gabbro, Maryland: Geol. Soc. America Bull., v. 62 , no. 9 , p. $979-1016$.

Southwick, David, 1969, Crystalline rocks of Harford County, in Geology of Harford County, Maryland: Baltimore, Md., Maryland Geol. Survey, p. 1-76.

Stose, A. J., and Stose, G. W., 1946, Physical features of Carroll and Frederick Counties: Baltimore, Md., Maryland Dept. Geology, Mines and Water Resources, $312 \mathrm{p}$.

Ward, R. F., 1959, Petrology and metamorphism of the Wilmington complex, Delaware, Pennsylvania, and Maryland: Geol. Soc. America, v. 70, no. 11, p. 1425-1458.

\section{VIRGINIA}

Allen, R. M., Jr., 1963, Geology and mineral resources of Greene and Madison Counties: Virginia Div. Mineral Resources Bull. 78, $102 \mathrm{p}$.

Bloomer, R. O., and Werner, H. J., 1955, Geology of the Blue Ridge region in central Virginia: Geol. Soc. America Bull., v. 66 , no. 5, p. 579-606.

Brown, W. R., 1958, Geology and mineral resources of the Lynchburg quadrangle, Virginia: Virginia Div. Mineral Resources Bull. 74, $99 \mathrm{p}$.

Conley, J. F., and Toewe, E. C., 1968, Geology of the 
Martinsville West quadrangle, Virginia: Virginia Div. Mineral Resources Rept. Inv. 16, 44 p.

Dietrich, R. V., 1959, Geology and mineral resources of Floyd County of the Blue Ridge Upland, southwestern Virginia: Virginia Polytech. Inst., Eng. Expt. Sta. Bull., Ser. no. 134, 160 p.

Ern, E. H., 1968, Geology of the Buckingham quadrangle, Virginia: Virginia Div. Mineral Resources Rept. Inv. 15, 45 p.

Espenshade, G. H., 1954, Geology and mineral deposits of the James River-Roanoke River manganese district: U.S. Geol. Survey Bull. 1008, 155 p.

Espenshade, G. H., and Potter, D. B., 1960, Kyanite, sillimanite, and andalusite deposits of the southeastern States: U.S. Geol. Survey Prof. Paper 336, $121 \mathrm{p}$.

Furcron, A. S., 1939, Geology and mineral resources of the Warrenton quadrangle, Virginia: Virginia Geol. Survey Bull. 54, 94 p.

Gooch, E. O.., 1958, Infolded metasedimentary rocks near the axial zone of the Catoctin Mountain-Blue Ridge anticlinorium in Virginia: Geol. Soc. America Bull., v. 69, no. 5, p. 569-574.

Hopkins, H. R.; 1960, Geology of western Louisa County, Virginia: Ithaca, N.Y., Cornell Univ., Ph.D. thesis.

Johnston, P. M., 1962, Geology and ground water resources of the Fairfax quadrangle, Virginia: U.S. Geol. Survey Water-Supply Paper 1539-L, 61 p.

Jonas, A. I., 1927, Geologic reconnaissance in the Piedmont of Virginia: Geol. Soc. America Bull. 38, no. 4, p. $837-846$.

1929, Structure of the metamorphic belt of the central Appalachians: Geol. Soc. America Bull., v. 40, no. 2, p. 503-513.

1932, Geology of the kyanite belt of Virginia: Virginia Geol. Survey Bull. 38, p. 1-38.

1932 , Structure of the metamorphic belt of the southern Appalachians: Am. Jour. Sci., 5th ser., v. 24, p. 228-243.

Jonas, A. I., and Stose, G. W., 1939, Age relation of the pre-Cambrian rocks in the Catoctin MountainBlue Ridge and Mount Rogers anticlinoria in Virginia: Am. Jour. Sci., v. 237, no. 8, p. 575-593.

Lonsdale, J. T., 1927, Geology of the gold pyrite belt of the northeastern Piedmont, Virginia: Virginia Geol. Survey Bull. 30, 110 p.

Nelson, W. A., 1962, Geology and mineral resources of Albemarle County: Virginia Div. Mineral Resources Bull 77, $92 \mathrm{p}$.

Nickelsen, R. P., 1956, Geology of the Blue Ridge near Harpers Ferry, West Virginia: Geol. Soc. America Bull., v. 67, no. 3, p. 239-269.

Parker, P. E., 1968, Geological investigation of the Lincoln and Bluemont quadrangles, Virginia: Virginia Div. Mineral Resources Rept. Inv. 14, $23 \mathrm{p}$.

Redden, J. A., 1963, Stratigraphy and metamorphism of the Altavista area, in Geological excursions in southwestern Virginia, Geol. Soc. America Southeastern Sec., Ann. Mtg., 1963: Virginia Polytech. Inst., Eng. Ext. Ser., Geol. Guidebook 2, p. 77-99.

Reed, J. C., Jr., 1955, Catoctin formation near Luray; Virginia: Geol. Soc. America Bull., v. 66, no. 7, p. 871-896.

Ross, C. S., 1941, Occurrence and origin of the titanium deposits of Nelson and Amherst Counties, Virginia: U.S. Geol. Survey Prof. Paper 198, 59 p.

Smith, J. W., Milici, R. C., and Greenberg, S. S., 1964, Geology and mineral resources of Fluvanna County, Virginia: Virginia Div. Mineral Resources Bull. $79,62 \mathrm{p}$.

Stose, A. J., and Stose, G. W., 1957, Geology and mineral resources of the Gossan Lead district and adjacent areas in Virginia: Virginia Div. Mineral Resources Bull. 72, $233 \mathrm{p}$.

Stose, G. W., and Stose, A. J., 1948, Stratigraphy of the Arvonia slate, Virginia: Am. Jour. Sci., v. 246, no. 7 , p. 394-412.

Taber, Stephen, 1913, Geology of the gold belt in the James River basin, Virginia: Virginia Geol. Survey Bull. 7, 271 p.

Toewe, C. E., 1966, Geology of the Leesburg quadrangle, Virginia: Virginia Div. Mineral Resources Rept. Inv. 11, $52 \mathrm{p}$.

Werner, H. J., 1966, Geology of the Vesuvius quadrangle, Virginia: Virginia Div. Mineral Resources Rept. Inv. 7, $53 \mathrm{p}$.

\section{NORTH CAROLINA}

Butler, J. R., 1963, Rocks of the Carolina slate belt in Orange County, North Carolina: Southeastern Geology, v. 4, no. 3, p. 167-185:

Brobst, D. A., 1962, Geology of the Spruce Pine district, Avery, Mitchell, and Yancy Counties, North Carolina: U.S. Geol. Survey Bull. 1122-A, $26 \mathrm{p}$.

Brown, H. S., 1962, Geology of the Elk Knob copper deposit and vicinity, Wautauga County, North Carolina: Southeastern Geology, v. 3, no. 4, p. 231-249.

Bryant, Bruce, 1962, Geology of the Linville quadrangle; North Carolina-Tennessee: U.S. Geol. Survey, Bull. 1121-D, $30 \mathrm{p}$.

Carpenter, R. H., 1967, Regional metamorphism in the western Blue Ridge of Tennessee and North Carolina: Knoxville, Tenn., Tennessee Valley Authority, Div. Water Control Planning, Geol. Br., $25 \mathrm{p}$.

Conley, J. F., 1962a, Geology of the Albemarle quadrangle, North Carolina: North Carolina Div. Mineral Resources Bull. 73, 26 p:

1962b, Geology and mineral resources of Moore County, North Carolina: North Carolina Div. Mineral Resources Bull. 76, 40 p.

Conley, J. F., and Bain, G. L., 1965, Geology of the Carolina slate belt west of the Deep River-Wadesboro 
Triassic basin, North Carolina: Southeastern Geology, v. 6, no. 3, p. 117-138.

Eckelmann, F. D., and Kulp, J. L., 1956, The sedimentary origin and stratigraphic equivalence of the socalled Cranberry and Henderson granites in western North Carolina: Am. Jour. Sci., v 254, no. 5, p. 288-315.

Espenshade, G. H., 1947, Tungsten deposits of Vance County, North Carolina, and Mecklenburg County, Virginia: U.S. Geol. Survey Bull. 948-A, 17 p.

1967, Reconnaissance geologic map of the Yadkin Valley region, North Carolina: U.S. Geol. Survey, open-file map, 2 sheets.

Espenshade, G. H., and Potter, D. B., 1960, Kyanite, sillimanite, and andalusite deposits of the southeastern States: U.S. Geol. Survey Prof. Paper 336, $121 \mathrm{p}$.

Furbish, W. J., 1967, Chloritoid from Orange County, North Carolina: Southeastern Geology, v. 8, no. 2, p. 53-66.

Hadley, J. B., 1949, Preliminary report on corundum deposits in the Buck Creek peridotite, Clay County, North Carolina: U.S. Geol. Survey Bull. 948-E, p. 103-128.

Hadley, J. B., and Goldsmith, Richard, 1963, Geology of the eastern Great Smoky Mountains, North Carolina and Tennessee: U.S. Geol. Survey Prof. Paper 349-B, $118 \mathrm{p}$.

Hadley, J. B., and Nelson, A., 1971, Geologic map of the Knoxville quadrangle, North Carolina, Tennessee, and South Carolina: U.S. Geol. Survey Misc. Geol. Inv. Map I-654.

Hadley, J. B., King, P. B., Neuman, R. B., and Goldsmith, Richard, 1955, Outline of the geology of the Great Smoky Mountains area, Tennessee and North Carolina, in Russell, R. J., ed., Guides to southeastern geology: New York, Geol. Soc. America, p. 390-427.

Hunter, C. E., and White, W. A., 1946, Occurrences of sillimanite in North Carolina: North Carolina Div. Mineral Resources Inf. Circ. 4, $13 \mathrm{p}$.

Griffitts, W. R., and Overstreet, W. C., 1952, Granitic rocks of the western Carolina Piedmont: Am. Jour. Sci., v. 250 , no. 11 , p. $777-789$.

Kesler, T. L., 1955, The Kings Mountain area, in Russell, R. J., ed., Guides to southeastern geology: New York, Geol. Soc. America, p. 374-387.

King, P. B., 1955, A geologic section across the southern Appalachians; an outline of the geology in the segment in Tennessee, North Carolina, and South Carolina, in Russell, R. J., ed., Guides to southeastern geology: New York, Geol. Soc. America, p. 332-373.

Kulp, J. L., and Poldervaart, Arie, 1956, The metamorphic history of the Spruce Pine district: Am. Jour. Sci., v. 254, no. 7, p. 393-403.

Laney, F. B., 1910, The Gold Hill mining district of North Carolina: North Carolina Geol. Survey Bull. 21, 137 p.
1917, The geology and ore deposits of the Virgilina district of Virginia and North Carolina: North Carolina Geol. Survey Bull. 26, 176 p.; also pub. as Virginia Geol. Survey Bull. 14.

Overstreet, W. C., and Griffitts, W. R., 1955, Inner Piedmont belt, in Russell, R. J., ed., Guides to southeastern geology: New York, Geol. Soc. America, p. 549-577.

Overstreet, W. C., Yates, R. G., and Griffitts, W. R., 1963, Geology of the Shelby quadrangle, North Carolina: U.S. Geol. Survey Misc. Geol. Inv. Map I-384.

Parker, J. M., 3d, 1964, The mile-long section of metamorphic rocks at Roanoke Rapids, North Carolina [abs.]: Elisha Mitchell Soc. Jour., v. 80, no. 2, p. 164.

1968, Structure of easternmost North Carolina Piedmont: Southeastern Geology, v. 9, no. 3, p. 117-132:

Parker, J. M., and Broadhurst, S. D., 1959, Guidebook for Piedmont field trip, featuring metamorphic facies in the Raleigh area, North Carolina, April 16, 1959: Geol. Soc. America, Southeastern Sec., 24 p.

Rankin, D. W., 1970, Stratigraphy and structure of Precambrian rocks in northwestern North Carolina, in Fisher, G. W., and others, eds., Studies of Appalachian geology-central and southern: New York, Interscience Publishers, p. 227-245.

Reed, J. C., Jr., 1964, Geology of the Linville Falls quadrangle, North Carolina: U.S.' Geol. Survey Bull. 1161-B, 53 p.

Stromquist, A. A., and Sundelius, H. W., 1969, Stratigraphy of the Albemarle Group of the Carolina slate belt in central North Carolina: U.S. Geol. Survey Bull. 1274-B, 22 p.

Stuckey, J. L., 1926, Chloritoid from the Deep River region, North Carolina: Am. Mineralogist, v. 11, no. 7, p. 186-188.

Tobisch, 0. T., and Glover, Lynn, 1969, Metamorphic changes across part of the Carolina slate beltCharlotte belt boundary, North Carolina and Virginia: U.S. Geol. Survey Prof. Paper 650-C, p. C1-C7.

Van Horn, E. C., 1948, Talc deposits of the Murphy marble belt: North Carolina Div. Mineral Resources Bull. 56, $54 \mathrm{p}$.

Wilcox, R. E., and Poldervaart, Arie, 1958, Metadolerite dike swarm in Bakersville-Roan Mountain area, North Carolina: Geol. Soc. America Bull., v. 69 , no. 11 , p. $1323-1367$.

Zen, E-an, 1961, Mineralogy and petrology of the system $\mathrm{Al}_{2} \mathrm{O}_{3}-\mathrm{SiO}_{2}-\mathrm{H}_{2} \mathrm{O}$ in some pyrophyllite deposits of North Carolina: Am. Mineralogist, v. 46 , nos. $1-2$, p. 52-66.

\section{SOUTH CAROLINA}

Brown, C. Q., 1966, Sillimanite in Pickens County, South Carolina: South Carolina Div. Geology Geol. Notes, v. 10, no. 1, p. 4-7. 
Brown, C. Q., and Cazeau, C. J., 1964, Geology of the Clemson quadrangle, South Carolina: South Carolina Div. Geology Map Ser. MS-9.

Butler, J. R., and Siple, G. E., 1966, Geology and mineral resources of York County, South Carolina: South Carolina Div. Geology Bull. 33, 65 p.

Cazeau, C. J., 1966, Geology of the La France quadrangle, South Carolina: South Carolina Div. Geology Map Ser. MS-10. 1967, Geology and mineral resources of Oconee County, South Carolina: South Carolina Div. Geology Bull. 34, 38 p.

Cazeau, C. J., and Brown, C. Q., 1963, Guide to the geology of Pickens and Oconee Counties, South Carolina: South Carolina Div. Geology, Geol. Notes, v. 7, p. 31-40.

Clarke, J. W., 1957, Contact metamorphism in Laurens County, South Carolina: South Carolina Div. Geology. Mineral Industries Lab. Monthly Bull., v. 1 , no. 4, p. 2-7.

Fries, Carl, Jr., 1942, Topaz deposits near the Brewer mine, Chesterfield County, South Carolina: U.S. Geol. Survey Bull. 936-C, p. 59-78.

Griffitts, W. R., and Overstreet, W. E., 1952, Granitic rocks of the western Carolina Piedmont: Am. Jour. Sci., v. 250, no. 11, p. 777-789.

Hatchell, W. O., 1964, Petrology of metasedimentary and volcanic rocks along Harmon Creek in the Irmo N.E. quadrangle, South Carolina: South Carolina Div. Geology, Geol. Notes, v. 8, nos. 3-4, p. 35-45.

McCauley, J. F., 1961a, Relationships between the Carolina slate belt and the Charlotte belt in Newberry County, South Carolina: South Carolina Div. Geology, Geol. Notes, v. 5, no. 5, p. 59-66.

$1961 \mathrm{~b}$, Rock analyses in the Carolina slate belt and the Charlotte belt of Newberry County, South Carolina: Southeastern Geology, v. 3, no. 1, p. $1-20$.

Overstreet, W. C., and Bell, Henry, 3d, 1965, The crystalline rocks of South Carolina: U.S. Geol. Survey Bull. 1183, 126 p.

Overstreet, W. C., and Griffitts, W. R., 1955, Inner Piedmont belt, in Russell, R. J., ed., Guides to southeastern geology: New York, Geol. Soc. America, p. 549-577.

Wagener, H. D., 1966, Coarse-grained sillimanitequartz rock associated with the Winnsboro granites, Fairfield County, South Carolina: South Carolina Div. Geology, Geol. Notes, v. 10, no. 3, p. 43-45.

\section{GEORGIA}

Applin, P. L., 1952, Preliminary report on buried preMesozoic rocks in Florida and adjacent States: U.S. Geol. Survey Circ. 91, 28 p.

Bayley, W. S., 1928, Geology of the Tate quadrangle, Georgia: Georgia Geol. Survey Bull. 43, 170 p.

Clarke, J. W., 1952, Geology and mineral resources of the Thomaston quadrangle, Georgia: Georgia Geol.
Survey Bull. 59, 99 p.

Cofer, H. E., 1958, Structural relations of the granites and associated rocks of south Fulton County, Georgia [abs.]: Dissert. Abs. v. 18, no. 5, p. 17681769.

Crawford, J. J., Hurst, V. J., and Ramspott, L. D., 1966, Extrusive volcanic rocks and associated dike swarms in central-east Georgia-Geol. Soc. America, Southeastern Sec., Field Trip no. 2, 1966, Guidebook: Athens, Ga., Univ. Georgia Dept. Geology, 53 p.

Crickmay, G. W., 1935a, Kyanite in Fulton County: Georgia Geol. Survey Bull. 46, p. 36-37.

1935b, Kyanite in Talbot and Upson Counties: Georgia Geol. Survey Bull. 46, p. 32-36.

1936, Status of the Talladega series in southern Appalachian stratigraphy: Geol. Soc. America Bull., v. 37, no. 9, p. 1371-1392.

1952, Geology of the crystalline rocks of Georgia: Georgia Geol. Survey Bull. 58, 54 p.

Eckel, E. C., 1903, Gold and pyrite deposits of the Dahlonega district, Georgia: U.S. Geol. Survey Bull. 213, p. 57-63.

Fairley, W. M., 1965, The Murphy syncline in the Tate quadrangle, Georgia: Georgia Geol. Survey Bull. $75,71 \mathrm{p}$.

Furcron, A. S., 1960, Kyanite, sillimanite, and andalusite in Georgia: Georgia Mineral Newsletter, v. 13 , no. 1 , p. 9-21.

Furcron, A. S., and Teague, K. H., 1945, Sillimanite and massive kyanite in Georgia: Georgia Geol. Survey Bull. 51, 76 p.

Furcron, A. S., Teague, K. H., and Calver, J. L., 1946 , Talc deposits of Murray County, Georgia: Georgia Geol. Survey Bull. 53, 75 p.

Grant, W. H., 1958, Geology of Hart County, Georgia: Georgia Geol. Survey Bull. 67, 75 p.

Herrmann, L. A., 1954, Geology of the Stone MountainLithonia district, Georgia: Georgia Geol. Survey Bull. 61,139 p.

Hewett, D. F., and Crickmay, G. W., 1937, The warm springs of Georgia: U.S. Geol. Survey WaterSupply Paper 819, 40 p.

Hudson, W. C., 1946, Exploration of Georgia and South Carolina sillimanite deposits: U.S. Bur. Mines Rept. Inv. 3927, 44 p.

Hurst, V. J., 1955, Stratigraphy, structure, and mineral resources of the Mineral Bluff quadrangle, Georgia: Georgia Geol. Survey Bull. 63, 137 p.

1959, The geology and mineralogy of Graves Mountain, Georgia: Georgia Geol. Survey Bull. $68,33 \mathrm{p}$.

Hurst, V. J., and Crawford, T. J., 1964, Exploration of mineral deposits in Habersham County, Georgia: U.S. Dept. Commerce, Area Redevel. Adm., 180 p.

Hurst, V. J., and Otwell, W. L., 1964, Exploration of mineral deposits in White County, Georgia: U.S. Dept. Commerce, Area Redevel. Adm., 166 p.

Kesler, T. L., 1950, Geology and mineral deposits of the Cartersville district, Georgia: U.S. Geol. Survey. 
Prof. Paper 224, 97 p.

LaForge, Laurence, and Phalen, W. C., 1913, Description of the Ellijay quadrangle [Georgia, North Carolina, and Tennessee]: U.S. Geol. Survey Geol. Atlas, Folio 187.

McCollum, M. J., 1966, Ground-water resources and geology of Rockdale County, Georgia: Georgia Geol. Survey Inf. Circ. 33, 17 p.

Medlin, J. H., and Hurst, V. J., 1967, Geology and mineral resources of the Bethesda Church area, Greene County, Georgia: Georgia Geol. Survey Inf. Circ. 35, 29 p.

Ramspott, L. D., 1964, The Elberton batholith: Southeastern Geology, v. 5, no. 4, p. 223-230.

Salisbury, J. W., 1961, Geology and mineral resources of the northwest quarter of the Cohutta Mountain quadrangle: Georgia Geol. Survey Bull. 71, 61 p.

Salotti, C. A., and Fouts, J. A., 1967, An occurrence of cordierite-garnet gneiss in Georgia: Am. Mineralogist, v. 52, nos. $7-8$, p. $1240-1243$.

Sever, C. W., 1964, Geology and ground-water resources of crystalline rocks, Dawson County, Georgia: Georgia Geol. Survey Inf. Circ. 30, 32 p.

Smith, J. W., 1969, Isotopic dating and metamorphic isograds of the crystalline rocks of Georgia, in Precambrian-Paleozoic Appalachian problems: Georgia Geol. Survey Bull. 80, p. 121-139.

Webb, J. E., 1958, Reconnaissance geologic survey of parts of Polk and Haralson Counties: Georgia Mineral Newsletter, v. 11, no. 1, p. 19-24.

\section{ALABAMA}

Adams, G. I., 1926, Geology of Alabama; The crystalline rocks: Alabama Geol. Survey Spec. Rept. 14, p. 25-40.

1933, General geology of the crystallines of Alabama: Jour. Geology, v. 41, no. 2, p. 159-173.

Alabama Geological Society, 1964 Alabama Piedmont geology, 2d Annual Field Trip, December 1964, Guidebook: University, Ala., Alabama Geol. Soc., $64 \mathrm{p}$.

Bergquist, H. R.,1960, Petrographic study of the crystalline rocks from the Opelika quadrangle, Alabama: Alabama Geol. Survey Bull. 69, 44 p.

Brown, J. S., 1925, Graphite deposits of Ashland, Alabama: Econ. Geology, v. 20, no. 3, p. 208-248.

Carrington, T. J., and Wigley, Perry, 1967, Redefinition of the Hillabee Schist, Alabama: Southeastern Gtolugy, v. 8, no. 1, p. 19-32.

Gault, H. R., 1945, Petrography, structures and petrofabrics of the Pinckneyville quartz diorite, Alabama: Geol. Soc. America Bull., v. 56, no. 2, p. 181-246.

Griffin, R. H., 1951, Structure and petrography of the Hillabee sill and metamorphics of Alabama: Alabama Geol. Survey Bull. 63, 74 p.

Heinrich, E. W., and Olson, J. C., 1953, Mica deposits of the southeastern. Piedmont. Part 11, Alabama district: U.S. Geol. Survey Prof. Paper 248-G, p. 401-462.

Hunter, F. R., 1944, Geology of the Alabama tin belt: Alabama Geol. Survey Bull., v. 54, 61 p.

Neathery, T. L., 1967, Paragenesis of the Turkey Heaven Mountain kyanite deposits, Cleburn County, Alabama: Alabama Geol. Survey Circ. 41, 56 p. 1968, Talc and anthophyllite asbestos deposits in Tallapoosa and Chambers Counties, Alabama: Alabama Geol. Survey Bull. 90, 98 p.

Neathery, T. L., LeVan, H. P., Ahrenholz, H. W., and O'Neill, J. F., 1967, Talc and asbestos at Dadeville, Alabama: U.S. Bur. Mines Rept. Inv. 7045, 57 p.

Prouty, W. F., 1916, Preliminary report on the crystalline and other marbles of Alabama: Alabama Geol. Survey Bull. 18, 212 p. 1923, Geology and mineral resources of Clay County, Alabama: Alabama Geol. Survey County Rept. no. 1, 190 p. 